Marek Rewizorski

Uniwersytet Gdański

\title{
Globalne zarządzanie w perspektywie transnarodowego materializmu historycznego
}

DOI: $10.19195 / 1643-0328.21 .2$

Słowa kluczowe: transnarodowy materializm historyczny, globalne zarządzanie, gospodarka kapitalistyczna, komodyfikacja, globalizacja, liberalizacja

\section{Wprowadzenie}

Na przełomie XX i XXI wieku globalizacja z często charakteryzowanego zjawiska czy też procesu — definiowanego niezliczoną liczbę razy z perspektyw: ekonomicznej, politycznej, społecznej, kulturowej - dość niepostrzeżenie stała się matrycą dla rozwoju różnorodnych form zarządzania. Ich spektrum określa się mianem globalnego zarządzania (ang. global governance). Można postawić tezę, że global governance to zarządzanie w dobie globalizacji, zachodzące głównie, choć nie jedynie, w sferze ekonomicznej. Krytyczne podejście do globalnego zarządzania prezentują zwolennicy nurtu, który określa się mianem transnarodowego materializmu historycznego. Twierdzą oni, że wyżej wskazany koncept ma za zadanie maskować klasowy charakter praktyk sterowania zachodzących w ekonomii kapitalistycznej. Wspólnym mianownikiem jest dla nich historyzacja relacji między globalizacją, komodyfikacją i liberalizacją — procesami, które stały się szczególnie widoczne na przełomie lat 70. i 80. ubiegłego wieku. Zdaniem materialistów historycznych rezultatem ideowego patchworku jest globalizacja neoliberalna stanowiąca nie tyle proces nowy, ile raczej najnowszą odsłonę fenomenu, który zachodzi od ponad 500 lat. Krytykując prezentyzm neoliberalnego modelu globalnego zarządzania, materialiści zaproponowali jego historyzację przez ukazanie kolejnych etapów procesu komodyfikacji i penetracji wszystkich dziedzin życia ludzkiego przez motyw zysku.

Celem niniejszego artykułu jest próba usystematyzowania różnorodnych stanowisk wyrażanych przez transnarodowych materialistów historycznych w odniesieniu do globalnego zarządzania. W jego pierwszej części zostanie ukazana materialistyczna krytyka ONZ-owskiej wizji globalnego zarządzania. W drugiej — analizowana problematyka zostanie osadzona w warstwie teoretycznej, opartej na pracach między innymi 
Immanuela Wallersteina, Henka Overbeeka, Roberta Coxa, Marka Duffielda i Stephena Gilla. Artykuł zakończą wnioski zawierające spostrzeżenia i uogólnienia wynikające z poczynionych rozważań.

\section{Globalne zarządzanie i jego materialistyczna krytyka}

Punktem wyjścia w konstruowaniu wizji globalnego zarządzania jest dla transnarodowych materialistów historycznych krytyka najszerzej reprezentowanego ujęcia tego fenomenu, wypracowanego przez Komisję ds. Globalnego Zarządzania ONZ. Zostało ono uznane za „zarządzanie bez rządu”. W raporcie Our Global Neighborhood Komisja uznała, że składa się na nie: „ogół wielu sposobów, w jaki jednostki oraz instytucje publiczne i prywatne kierują swymi wspólnymi sprawami. Jest to ciągły proces, za pomocą którego godzi się odmienne interesy i podejmuje współdziałanie" ${ }^{1}$. Za środki realizacji globalnego zarządzania wskazana wspólnota epistemiczna uznała formalne oraz nieformalne instytucje i reżimy uprawomocnione do egzekwowania podporządkowania, a także nieformalne kompromisy między ludźmi i instytucjami.

Odnosząc się do tej propozycji definicyjnej, mającej za podbudowę teoretyczną liberalny instytucjonalizm, materialiści historyczni zaznaczyli, że trudno ją zaakceptować, $\mathrm{i}$ to $\mathrm{z}$ trzech powodów. Po pierwsze, global governance w ujęciu zaproponowanym przez ekspertów ONZ ma znaczenie normatywne i określa konsensualny proces przystosowania stron, którego najwyższym celem jest rekoncyliacja możliwych konfliktów. Wyklucza to konotację odnoszącą się do dominacji i siły. Po drugie, definicja ta podkreśla pluralizm aktorów globalnego zarządzania, ich interesy i struktury, które James Rosenau

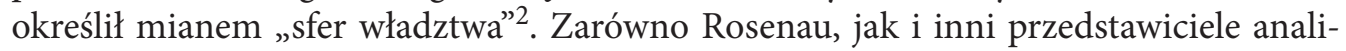
tycznego nurtu global governance wskazali na niezdeterminowany i neutralny charakter pluralizmu, podczas gdy według materialistów jest on zanurzony w hierarchicznej konfiguracji władzy społecznej. Po trzecie, analizowana definicja jest zdaniem materialistów ahistoryczna, tj. odrywa się od krytycznych momentów, których zachodzenie leży u podstaw globalnego zarządzania ${ }^{3}$.

Wskazując na dwa elementy pojęcia global governance, przedstawiciele materializmu historycznego zauważyli ponadto, że to, co jest „globalne”, ma wymiar planetarny, jest światowe, obejmujące swoim zasięgiem glob, natomiast „zarządzanie” nasuwa skojarzenia z regulacją, koordynacją, autorytatywną alokacją wartości czy organizowaniem działań kolektywnych. W związku z tym stanęli na stanowisku, że globalne zarządzanie należałoby raczej określać jako „autorytatywną alokację [...] wartości w dziedzinach

\footnotetext{
${ }^{1}$ Commission on Global Governance, Our Global Neighborhood, Oxford 1995, s. 2.

2 J.N. Rosenau, Governance in a new global order, [w:] Governing Globalization: Powers, Authority and Global Governance, red. D. Held, A. McGrew, Cambridge 2002, s. 70-86.

${ }^{3}$ H. Overbeek, Global governance, class, hegemony. A historical materialist perspective, [w:] Contending Perspectives on Global Governance. Coherence, Contestation and World Order, red. A.D. Ba, M.J. Hoffman, London-New York 2005, s. 39-40.
} 
polityki, które potencjalnie wpływają na świat jako całość i na jego części składowe"4. Zdaniem materialistów historycznych zachodzi ona na poziomie transnarodowym. Taki też charakter ma współczesny kapitalizm. Tworzą go transnarodowe procesy ukonstytuowane w przestrzeni społecznej i wykraczające poza granice państwowe. Jak wskazuje Samuel Huntington, procesy te charakteryzuje jednoczesność zachodzenia na wielu arenach $^{5}$. Tworzy to wrażenie rozszerzającej się sieci relacji społecznych obejmujących lokalne, narodowe, regionalne struktury. W tym znaczeniu tradycyjny podział na to, co „państwowe”, i to, co „międzynarodowe”, traci na znaczeniu.

\section{Historyzacja globalnego zarządzania}

Transnarodowi materialiści historyczni rozpoczynają swoją analizę od osadzenia globalnego zarządzania w perspektywie historycznej. Dowodzą, że jest ono zarządzaniem w erze globalizacji. W ujęciu Craiga N. Murphy'ego ${ }^{6}$, Ernesta Mandela ${ }^{7}$, Michaela Zür$\mathrm{na}^{8}$ oraz Henka W. Overbeeka globalizacja jest narracją historyczną zachodzącą na gruncie ekonomicznym i opisuje proces komodyfikacji (od angielskiego słowa commodity - towar), polegający na przetwarzaniu, transformowaniu rzeczy czy działań $\mathrm{w}$ produkty (towary) i usługi sprzedawane na rynku. Wiąże się z wykształceniem rynku globalnego, początkowo mającego charakter towarowy, później zaś także usługowy. Zdaniem tej grupy autorów związek między globalizacją a rynkiem nie jest ani nowy, ani też niepoznany. Zachodzi z różnym natężeniem od kilku wieków. W szczególności Overbeek, nawiązując do dzieł Immanuela Wallersteina $z$ lat 70. i 80. ubiegłego wieku ${ }^{9}$, zauważył związek między komodyfikacją i globalizacją. Tę ostatnią umieścił on na kontinuum

${ }^{4}$ Ibidem, s. 40.

${ }^{5}$ S.P. Huntington, Transnational organizations in world politics, [w:] Perspectives on World Politics, red. R. Little, M. Smith, London 1991, s. 212-228.

${ }^{6}$ C.N. Murphy, International Organization and Industrial Change. Global Governance since 1850, Cambridge 1994.

7 E. Mandel, Late Capitalism, London 1975.

8 M. Zürn, The change of globalization and individualization: A view from Europe, [w:] Whose World Order? Uneven Globalization and the End of Cold War, red. H.H. Holm, G. Sørensen, Boulder 1995.

${ }^{9}$ I. Wallerstein, bazując na ustaleniach tak zwanej szkoły zależności, której głównymi przedstawicielami byli C. Furtado i A. Gunder Frank, przedstawił model opisujący relacje między państwami rozwiniętymi i rozwijającymi się. Krytykując założenie o istnieniu centrum (rdzenia) i peryferii, sformułował koncepcję półperyferii. Ujmował je jako szczególną kategorię podmiotów oddzielających rdzeń od peryferii i jednocześnie swoistą klasę średnią stabilizującą spolaryzowany system światowy. Uwzględniając w swoich analizach „element pośredni”, Wallerstein doszedł do następujących wniosków: 1) nowoczesny system światowy stanowi kapitalistyczna gospodarka światowa, której podmioty dążą do nieustannej akumulacji kapitału; 2) zręby owego systemu ukształtowały się na przełomie XV i XVI wieku; 3) rozwój tak zdefiniowanego systemu światowego trwał kolejne stulecia, obejmując stopniowo nowe części świata; 4) kapitalistyczna gospodarka światowa została zdominowana przez relacje na linii centrum (rdzeń)-półperyferie-peryferie. Por. I. Wallerstein, The Capitalist-World Economy. Essays by Immanuel Wallerstein, Cambridge 1979, s. 53-68; idem, The Modern-World System III: The Second Era of Great Expansion of the Capitalist World-Economy 1730-1840, San Diego 1988; idem, Koniec świata jaki znamy, Warszawa 2004, s. 62-63; M. Re- 
czasowym, którego początek został wyznaczony przez nastanie epoki wielkich odkryć geograficznych (przełom XV i XVI wieku) i wykształcenie właściwej temu okresowi doktryny ekonomicznej, a koniec - przez pokój westfalski kończący wojnę trzydziestoletnią w Europie. Zdaniem Overbeeka w latach 1492-1648 globalizacja, przechodząc pierwszą fazę, przyjęła postać merkantylną. Wraz z ekspansją kapitału przemysłowego oraz nasilaniem dziewiętnastowiecznego imperializmu państw europejskich wkroczyła w drugą fazę (ok. 1840-1914), którą wspomniany autor określił mianem „globalizacji laissez-faire". Zakończył ją gwałtownie wybuch I wojny światowej. Według Overbeeka, od przełomu lat 70. i 80. ubiegłego wieku aż do dziś mamy do czynienia z globalizacją neoliberalną, trzecią fazą pięćsetletniego już procesu, który w ostatnich trzydziestu latach charakteryzuje się ekspansją transnarodowego kapitału na niespotykaną dotąd skalę $^{10}$. W tym okresie nastąpiło pogłębienie wszystkich działań, transakcji i powiązań, które zachodzą rynku. Przejawia się ono między innymi:

- ilościowym wzrostem jego różnorodnych form (np. zwiększeniem integracji rynków finansowych, wzrostem udziału usług w handlu międzynarodowym, rozwojem handlu wewnątrzgałęziowego, ekspansją przedsiębiorstw trans- i wielonarodowych, wzrostem znaczenia regulacji międzynarodowych o znaczeniu „globalnym” kosztem przepisów krajowych, deregulacją rynków finansowych, międzynarodową mobilnością kapitału, wzrostem fuzji i akwizycji, istnieniem niewielkich państw, mających wysoki stosunek obrotów handlu zagranicznego do PKB, jak Tajwan, Singapur, Finlandia, Irlandia);

- urynkowieniem sektorów dotychczas poddanych kontroli państwa (prywatyzacją przedsiębiorstw państwowych, także tych o strategicznym znaczeniu dla gospodarki narodowej, na przykład w sektorze telekomunikacyjnym, transportowym, energetycznym);

- inkorporacją (z pewnymi odrębnościami, na co wskazuje przykład Chin, państw skandynawskich) poszczególnych państw, a nawet regionów w ramy kapitalistycznego rynku globalnego, programowo odrzucającego gospodarki oparte na modelu socjalistycznym;

— podporządkowaniem poszczególnych sfer aktywności ludzkiej, także bardzo „zindywidualizowanych", jak reprodukcja czy twórczość artystyczna, bezosobowym i zautomatyzowanym siłom rynkowym.

Henk W. Overbeek charakteryzował trzy wspomniane epizody globalizacji, posługując się kategorią zmiany zawartej w logice historycznego procesu długiego trwania. Moderuje ona proces rozwoju kapitalizmu od jego najwcześniejszych form. Zdaniem Overbeeka obecny model kapitalizmu przejawiający się „neoliberalnym zarządzaniem” został wywołany przez trzecią, neoliberalną fazę globalizacji ${ }^{11}$.

Jak wspomniano, transnarodowi materialiści historyczni wyznaczyli jej początek na przełom lat 70. i 80. ubiegłego wieku. Uznali, że motorem przemian gospodarczych stał się wówczas kapitał finansowy i produkcyjny, który korzystając z kryzysów walutowych

wizorski, Koncepcja systemu światowego według Immanuela Wallersteina, „Przegląd Politologiczny” 2009, nr 1, s. 65-77.

${ }^{10}$ H. Overbeek, Global governance..., s. 43.

11 Ibidem. 
i naftowych z lat 1971-1979, odchodzenia od fordyzmu i keynesowskiego państwa dobrobytu, a także dynamicznego rozwoju nowych technologii w transporcie i komunikacji, stopniowo uwalniał się spod państwowej kurateli, co następowało pod hasłem walki z kryzysem. Neoliberałowie roztaczali wizję powrotu na ścieżkę prosperity gospodarczej dzięki przyznaniu większej swobody kapitałowi umożliwiającemu restrukturyzację przestrzennych i technicznych aspektów procesu produkcyjnego, jak również społecznych relacji produkcyjnych, w celu dostosowania wielkości produkcji do poziomu konsumpcji oraz przywrócenia zyskowności wytwórczej. Miało to nastąpić przez zwiększenie efektywności pracy. Za warunek wspomnianej restrukturyzacji materialiści historyczni uznali uwolnienie kapitału z rozmaitych ograniczeń, co znalazło wsparcie w koncepcji monetaryzmu. Zakładano w niej konieczność zachowania równowagi między podażą pieniądza, czyli jego ilością na rynku, a podażą dóbr, której zachwianie, przez nadmierne zwiększenie konsumpcji przy niezmienionej wielkości kapitału wytwórczego, prowadzi do wzrostu inflacji i realnego obniżenia dochodów obywateli. Monetaryzm programowo odrzucał interwencjonizm państwowy i był zwrotem ku klasycznej, dziewiętnastowiecznej wierze w samoregulującą moc działania mechanizmów rynkowych ${ }^{12}$. W postaci zwartej szkoły ekonomicznej monetaryzm wykształcił się w latach 50. ubiegłego wieku, po ukazaniu się kanonicznego dla tego nurtu myślenia tekstu Miltona Friedmana The quantity theory of money - a restatement ${ }^{13}$. Zyskał jednak na popularności dopiero w latach 70. XX wieku wraz z ukazaniem się artykułu Toward a new economics autorstwa amerykańskiego neokonserwatysty Irvinga Karola ${ }^{14}$. Nawoływał on do powrotu ku źródłom ekonomii opartym na liberalnych ideach Adama Smitha i odrzucenia popytowej teorii Keynesa. Duże znaczenie dla rozpowszechniania się monetaryzmu miało też pogłębianie się kryzysu ekonomicznego, dochodzenie do władzy neoliberalnych polityków, takich jak Margaret Thatcher, która objęła urząd premiera Wielkiej Brytanii w 1979 roku. Stałego wsparcia monetaryzmowi udzielali też tak zwani Chicago Boys, grupa uczniów i wyznawców poglądów, które propagował ich mistrz Milton Friedman - wykładający ekonomię na uniwersytecie w Chicago ${ }^{15}$. Na popu-

12 Przed I wojną światową monetaryzm jako doktryna ekonomiczna był niepopularny. Znajdował jednak uznanie u grupy ekonomistów, dziennikarzy i polityków, zwłaszcza w USA i Wielkiej Brytanii. Po 1945 roku propagowały go think tanki i prywatne grupy transnarodowe, takie jak Mont Pèlerin Society, założona w kwietniu 1947 roku przez F. Hayeka i M. Friedmana.

13 M. Friedman, The quantity theory of money - a restatement, „Studies in Quantity Theory of Money”, Chicago 1956.

14 I. Kristol, Toward a „new” economics, „The Wall Street Journal”, 9.05.1977; J. Żyżyński, Neoliberalizm - ślepa uliczka globalizacji, [w:] Globalizacja, kryzys i co dalej?, red. G. Kołodko, Warszawa 2010, s. 19.

15 Przykładowo zwolennicy poglądów M. Friedmana przejęli władzę w Chile rok po obaleniu w 1973 roku (w wyniku zamachu stanu) socjalistycznego prezydenta S. Allendego. W latach 1977-1981 PKB tego państwa wzrastał średnio o 8\% rocznie, co w dobie światowej recesji skłoniło R. Reagana do uznania Chile za model do naśladowania dla krajów Trzeciego Świata, a M. Friedmana do stwierdzenia, że „chilijski eksperyment można porównać z gospodarczym cudem powojennych Niemiec”. Co więcej, Chile, na co zwracają uwagę neoliberałowie, po ponad 30 latach reform wolnorynkowych w rankingu Index of Economic Freedom (Rankingu Wolności Gospodarczej) z 2007 roku stały się jedenastą najbardziej liberalną gospodarką świata i liderem regionalnym pod tym względem. W 2011 roku PKB tego państwa wzrósł o około 6\%, a liczba osób żyjących 
larność tej doktryny miało też wpływ objęcie fotela prezesa Banku Rezerwy Federalnej przez „neoliberalnego jastrzębia” Paula Volckera, który zainicjował w USA restrykcyjną politykę monetarystyczną.

Rozprzestrzenianie się monetaryzmu wpłynęło na osłabienie więzów społecznych oraz erupcję chciwości i indywidualizmu w państwach Zachodu. Jego bazę stanowili rentierzy i tak zwani venture capitalists - prywatni inwestorzy lokujący swój kapitał w inwestycjach obarczonych znaczną dozą ryzyka, osiągający zysk od wartości obejmowanego przedsiębiorstwa ${ }^{16}$. W latach 80 . najbardziej dochodowymi sektorami w gospodarce stały się: bankowość i usługi finansowe. Ostatecznie w miejsce modelu Keynesowskiego, rządzącego niepodzielnie w latach 1945-1971, monetaryzm zaproponował wartości oparte na prymacie wolnego rynku, komodyfikacji oraz wycofaniu się państwa

poniżej progu ubóstwa w 2012 roku (15,1\%, tyle samo co w USA), była znacznie mniejsza niż w pozostałych państwach Ameryki Południowej (Brazylia - 21,4\%, Argentyna - 30\%, Kolumbia - 37,2\%, Boliwia 51,3\%, Honduras $-60 \%$, Surinam $-70 \%$ ), a także niektórych państw europejskich (np. Polska $-17 \%$, Rumunia 21,1\%, Bułgaria - 21,8\%, Białoruś - 27,1\%, Ukraina - 35\%). Warto jednak zwrócić uwagę na ostrą krytykę chilijskiego modelu reform ze strony środowisk lewicowych. Już w 1983 roku W. Bello i J. Kelly wskazywali, że po okresie wzrostu PKB (lata 1977-1981) Chile doświadczyło załamania gospodarczego w 1982 roku wyrażającego się obniżeniem tego wskaźnika o prawie 13\%, czemu towarzyszył niezwykle wysoki wzrost liczby bezrobotnych (z 8 do 25\%), podczas gdy w 1973 roku za prezydentury S. Allendego bezrobocie wynosiło 3\%. Co więcej, wspominani autorzy zwrócili uwagę na ogromne zadłużenie zewnętrzne prywatnego sektora tego jedenastomilionowego kraju, wynoszące 17 miliardów USD w 1982 roku (z czego na 1983 rok przypadało do spłaty 3,6 mld USD). Bello i Kelly odpowiedzialnością za ten stan rzeczy obarczyli M. Friedmana i jego chilijskich uczniów kształconych na uniwersytecie w Chicago. Ci ostatni, dzięki zmianie polityki ekonomicznej, mieli umożliwić wprowadzenie w Chile „terapii szokowej”, zaaplikowanej temu krajowi przez Międzynarodowy Fundusz Walutowy i wielkie międzynarodowe banki, jak: Citicorp, Wells Fargo, Bank of America oraz Chase Manhattan, w których do końca 1981 roku chilijskie banki zaciągnęły pożyczki w astronomicznej, jak na owe czasy, kwocie 10 mld USD. Recesja doprowadziła też do ogromnego rozwarstwienia społecznego i spadku płac, widocznego szczególne w latach 80. (10-30\%). O społecznych aspektach "mitu chilijskiego cudu” pisała też N. Klein w swojej głośnej książce Doktryna szoku. Oskarżyła Pinocheta i „Chicago Boys” (m.in. S. de Castro - minister gospodarki, a następnie też finansów, J. Piňera - minister pracy) o wprowadzenie „terapii szokowej”, którą tygodnik „The Economist” uznał za „orgię samookaleczenia”. Jak wskazuje Klein, wynikiem wolnorynkowych reform w Chile było przejęcie dużej części krajowych aktywów przez zachodnie koncerny i wąską grupę finansistów (określanych jako piranhas) dorabiających się majątków na spekulacjach. Drastycznie okrojono też wydatki socjalne. W 1975 roku zmniejszyły się one o 27\%, a w 1980 roku były o połowę niższe niż w okresie rządów S. Allende. Co więcej, minister De Casto sprywatyzował około 500 państwowych banków i przedsiębiorstw oraz likwidował kolejne bariery dla importu. W konsekwencji w latach 1973-1983 gospodarka chilijska straciła 177 tys. miejsc pracy. Por. W. Bello, J. Kelly, The IMF and Chile. A parting of ways?, „The Multinational Monitor. International Finance” 4, 1983, nr 4; CIA World Factbook z 1 stycznia 2012, http://www.indexmundi.com/g/r.aspx?c=ci\&v=69 (dostęp: 20.03.2015); N. Klein, Doktryna szoku, Warszawa 2009, s. 97-117.

16 Obraz G. Gekko, bezlitosnego, niewahającego się łamać regulacji prawnych inwestora giełdowego z okresu monetarystycznej euforii trafnie ukazał amerykański reżyser O. Stone w swoim głośnym dramacie Wall Street (1987). Stworzony przez niego fikcyjny charakter, którego znakomicie zagrał M. Douglas, stał się popkulturowym symbolem chciwości korporacyjnego świata ze względu na powiedzenie: „chciwość, z braku lepszego słowa, jest dobra” (ang. greed for the lack of a better word, is good), http://usatoday30.usatoday.com/money/companies/regulation/story/2012-02-27/gordon-gekko-michael-doiuglas-fbi-psas/53275070/1 (dostęp: 20.03.2015). 
z zarządzania gospodarką. Jego główne idee (liberalizm, prywatyzacja, deregulacja i internacjonalizacja) wraz z nową indywidualistyczną etyką biznesu zyskały wiodącą pozycję w polityce, odsuwając w cień tradycyjny model „demokracji społecznej”. Na tę sytuację zwrócił uwagę Ralf Dahendorf, zauważając, że zwycięstwo neoliberalnej ortodoksji stanowi „koniec epoki socjaldemokratycznej” 17 .

Rozprzestrzeniający się od lat 70. neoliberalizm gospodarczy transnarodowi materialiści historyczni określili jako projekt hegemoniczny lub innymi słowy — kontrolę, która jest kształtowana przez konflikt, ustępstwa i ciągłą adjustację prowadzącą do konsolidacji neoliberalizmu zarówno na poziomie międzynarodowym, jak i wewnątrzpaństwowym. W takiej sytuacji każda wzmianka o alternatywie wobec rządów globalnego kapitału jest uważana za nierealistyczną i dyskredytowana jako niezgodna z obowiązującą ortodoksją. W tym kierunku podążył zwłaszcza Robert Cox. Starał się on wyjaśnić neoliberalny charakter globalnego zarządzania i sformułował koncepcję ,internacjonalizacji państwa" ${ }^{18}$. W jednym ze swoich esejów zanalizował mechanizmy podtrzymywania hegemonii w erze Pax Americana, stawiając tezę, że internacjonalizacja państwa wiąże się z ekspansją międzynarodowej produkcji. W często cytowanej pracy z 1987 roku wskazywał na istotę procesu internacjonalizacji, zauważając: „państwo staje się częścią większej i bardziej złożonej struktury politycznej, która jest odpowiednikiem międzynarodowej produkcji”" ${ }^{\prime 1}$. Starając się wyjaśnić wspomniany proces, Cox zwrócił uwagę na jego trzy podstawowe aspekty:

- formowanie się międzypaństwowego konsensusu dotyczącego potrzeb czy wymogów gospodarki światowej, co zachodzi w obrębie zespołu wspólnie przyjętych i akceptowanych idei;

- uczestnictwo w formowaniu konsensusu, które jest hierarchicznie strukturyzowane;

- dostosowywanie wewnętrznych struktur w państwach w taki sposób, żeby każda $\mathrm{z}$ nich była jak najlepszym narzędziem przeniesienia globalnego konsensusu do krajowej polityki ${ }^{20}$.

Według Coxa naturę neoliberalnego zarządzania określa globalna struktura klasowa wykraczająca poza krajowe struktury klasowe. Na jej szczycie znajduje się „transnarodowa klasa menedżerów (zarządców)", decydująca o działaniach podejmowanych między innymi przez Komisję Trilateralną, Międzynarodowy Fundusz Walutowy (MFW), Bank Światowy i Organizację Współpracy Gospodarczej i Rozwoju (OECD). Ta wąska grupa decydentów rozwinęła wspólne ramy myślenia i dyrektywy wskazujące, jak należy upowszechniać i zalecać rozwiązania dla poszczególnych państw w procesie ich internacjonalizacji ${ }^{21}$. Cox i inni materialiści zwrócili uwagę, że w niektórych obszarach władza finan-

17 Por. R. Dahrendorf, Die Chancen der Krise. Über die Zukunft des Liberalismus, Stuttgart 1983, s. 16; idem, Reflections on the Revolution in Europe, London 1994.

18 R.W. Cox, T.J. Sinclair, Approaches to World Order, Cambridge 1996, s. 107.

19 R.W. Cox, Production, Power, and World Order. Social Forces in the Making of History, New York 1987, s. 253. Na temat wpływu politycznych przekształceń na funkcjonowanie państw szerzej w: D. Held et al., Global Transformation. Politics, Economics and Culture, Redwood City 1999.

20 Ibidem, s. 254.

21 R.W. Cox, T.J. Sinclair, op. cit., s. 111. 
sowa jest sprawowana przez MFW i Bank Światowy, których znaczenie wzrosło od czasu kryzysu zadłużeniowego w latach 80 . Instytucje te podejmują działania wtedy, gdy kontrola nad rynkami słabnie lub jej brakuje. Ryzyko takie jest związane z transformacją systemu międzynarodowego po zakończeniu zimnej wojny, która usunęła wiele przeszkód na drodze do ekspansji rynków i oddziaływania kapitału transnarodowego. Reakcją na to zjawisko było uruchomienie środków gospodarczych o zasięgu światowym mających na celu ujęcie w karby wzrastającej siły oddziaływania inwestorów. Instytucje międzynarodowe, takie jak OECD, MFW, Bank Światowy oraz Światowa Organizacja Handlu (WTO), wsparte przez ugrupowania państw zachodnich G7/8, G20, stały się „strażnikami systemu", zaangażowanymi w prawną i polityczną reprodukcję praktyk o charakterze dyscyplinującym skupionych na regulacji, nadzorze i „warunkowaniu neoliberalnym” wszelkich przejawów działalności na rynkach finansowych, towarowych i usługowych.

$\mathrm{Na}$ dyscyplinujący wymiar global governance wskazali też Mark Duffield i Stephen Gill. Pierwszy z badaczy zauważył, że w najważniejszych obszarach gospodarki światowej owa "dyscyplina” przybiera postać „dobrowolnych" programów deregulacyjnych i kontroli finansowej, których podstawy są zawarte w takich porozumieniach międzynarodowych, jak na przykład liberalizacyjny reżim handlowy WTO ${ }^{22}$ czy Pakt stabilności i wzrostu (ang. Stability and Growth Pact) z 1997 roku. Zakłada on, że kryteria fiskalne z Maastricht są nie tylko warunkiem przyjęcia do Europejskiej Unii Monetarnej, lecz będą obowiązywać państwa członkowskie już po przyjęciu do unii walutowej. Z kolei Gill odwołał się do erozji kontroli demokratycznej, którą wiąże z procesem „nowego konstytucjonalizmu", polegającego na dążeniu w kierunku konstrukcji prawnych, konstytucyjnych urządzeń do usuwania lub izolowania nowych instytucji gospodarczych z powszechnej kontroli i demokratycznej odpowiedzialności ${ }^{23}$.

\section{Podsumowanie}

Reasumując powyższe rozważania, przedstawiciele transnarodowego materializmu historycznego zakładają, że koncepcja globalnego zarządzania zyskała popularność w dobie ekspansji globalizacji neoliberalnej, tj. w latach 80. ubiegłego wieku. Zarządzanie w erze globalizacji charakteryzuje się ich zdaniem nieformalnością i transnacjonalizacją. Innymi słowy, cechą szczególną global governance jest wytworzenie się struktur formalnych i nieformalnych mających zasoby potrzebne do tego, by sterować i zachować autonomię, funkcjonując przy tym ponad granicami państw. Przykładami mogą być MFW czy WTO, które zyskały znaczną autonomię od ustanawiających je państw, mimo że nominalnie państwa te sprawują kontrolę nad organami wykonawczymi tychże organizacji. Z kolei struktury nieformalne, jak G8, Swiatowe Forum Gospodarcze, a w ostatnich

22 M. Duffield, Global Governance and the New Wars. The Merging of Development and Security, London 2011.

23 S.R. Gill, Economic globalization and the internationalization of authority: Limits and contradictions, „Geoforum” 23, 1992, nr 3, s. 269-283. 
latach również G20, zaczęły odgrywać zasadniczą rolę w formułowaniu długoterminowych kierunków polityki obejmującej całą społeczność międzynarodową. Zdaniem materialistów znamienne jest też pojawienie się wielu centrów zarządzania i jego trybów obejmujących między innymi kombinację regulacji między- i transnarodowej, reżimów publiczno-prywatnych, form władztwa prywatnego i samoregulacji. Wspomniany już kilkakrotnie Robert Cox określił wyłanianie się nowych struktur, często przez kombinację sił publicznych i prywatnych, mianem „globalnej mgławicy” (fr. Global Nébuleuse) ${ }^{24}$.

Transnarodowi materialiści historyczni zaznaczają, że organizacje takie jak MFW, OECD czy Bank Światowy służą nadawaniu kierunku „globalnej mgławicy”. Najczęściej nie przysługuje im władza regulacyjna. Nie mogą one formalnie narzucić swojej woli państwom. Z kilkoma wyjątkami (np. Organ Rozstrzygania Sporów WTO) nie dysponują też uprawnieniami sankcyjnymi. Mimo to organizacje te dysponują zasobami politycznymi wyrażającymi się wpływem i znacznym prestiżem, co sprawia, że większość państw, choć niechętnie, zgadza się postępować w zgodzie z rekomendacjami płynącymi ze strony tychże organizacji. Podobny pogląd wyraziła Susan Strange, zauważając, że zarówno formalne, jak i nieformalne podmioty dysponujące znaczną dozą autonomii i zasobów pełnią funkcję „wytwórców idei”, które są rozpowszechniane przy pomocy wyższych rangą urzędników, władz wykonawczych w przedsiębiorstwach międzynarodowych, specjalistów i ekspertów zasiadających w grupach roboczych, spotykających się na konferencjach i tworzących wspólnoty epistemiczne ${ }^{25}$.

Zdaniem przedstawicieli transnarodowego materializmu historycznego najważniejsi aktorzy neoliberalnego global governance działają jak projektanci, wytwórcy, a zarazem nadzorcy. Niczym strażnicy ze świata znanego z filmu Matrix zajmują się kontrolą istniejącego systemu i zwalczaniem, dyskredytowaniem, eliminowaniem wszelkich możliwych alternatyw. Realizując funkcję nadzorczą, skupiają się na: 1) komunikacji - przez kontrolę kanałów komunikacyjnych między politykami, ekspertami oraz pozostałymi stronami, które zgłaszają zainteresowanie daną tematyką (np. przedstawicielami państw mających status obserwatorów w WTO); 2) socjalizacji - przez włączenie reprezentantów poszczególnych państw i ekspertów w ramy istniejących wspólnot epistemicznych, mających opiniotwórczy charakter i cieszących się dużym poważaniem ze względu na zasoby wiedzy, którymi dysponują; 3) instytucjonalizacji - celem tutaj jest zabezpieczenie prowadzenia reform wedle pożądanego wzorca neoliberalnego w państwach peryferyjnych i półperyferyjnych; 4) integracji - na co wskazuje przykład Polski i innych państw postsocjalistycznych. Państwa te w celu zapewnienia sobie akcesji do struktur UE i OECD musiały nie tylko poddać się długookresowym przygotowaniom, które można by określić mianem „politycznej kwarantanny”, lecz także przyjąć określony (neoliberalny) model polityki gospodarczej. Nade wszystko jednak dla zwolenników transnarodowego materializmu historycznego globalne zarządzanie jest procesem maskującym silnie hegemoniczny koncept, którego treść zależy od dyktatu transnarodowego kapitału.

24 R.W. Cox, T.J. Sinclair, op. cit., s. 298.

25 S. Strange, The Retreat of the State. The Diffusion of Power in the World Economy, Cambridge 1996, s. 62. 


\section{Bibliografia}

Bello W., Kelly J., The IMF and Chile. A parting of ways?, „The Multinational Monitor. International Finance" 4, 1983, nr 4.

Commission on Global Governance, Our Global Neighborhood, Oxford University Press, Oxford 1995.

Cox R.W., Production, Power, and World Order. Social Forces in the Making of History, Columbia University Press, New York 1987.

Cox R.W., Sinclair T.J., Approaches to World Order, Cambridge University Press, Cambridge 1996.

Dahrendorf R., Die Chancen der Krise. Über die Zukunft des Liberalismus, Deutsche Verlags-Anstalt, Stuttgart 1983.

Dahrendorf R., Reflections on the Revolution in Europe, Chatto and Windus, London 1994.

Duffield M., Global Governance and the New Wars. The Merging of Development and Security, Zed Books, London 2011.

Friedman M., The quantity theory of money - a restatement, „Studies in Quantity Theory of Money”, Chicago 1956.

Gill S.R., Economic globalization and the internationalization of authority: Limits and contradictions, „Geoforum" 23, 1992, nr 3.

Held D. et al., Global Transformation. Politics, Economics and Culture, Stanford University Press, Redwood City 1999.

Huntington S.P., Transnational organizations in world politics, [w:] Perspectives on World Politics, red. R. Little, M. Smith, Routledge, London 1991.

Klein N., Doktryna szoku, Muza, Warszawa 2009.

Kristol I., Toward a „new” economics, „The Wall Street Journal”, 9.05.1977.

Overbeek H., Global governance, class, hegemony. A historical materialist perspective, [w:] Contending Perspectives on Global Governance. Coherence, Contestation and World Order, red. A.D. Ba, M.J. Hoffman, Routledge, London-New York 2005.

Mandel E., Late Capitalism, Verso Books, London 1975.

Murphy C.N., International Organization and Industrial Change. Global Governance since 1850, Polity Press, Cambridge 1994.

Rewizorski M., Koncepcja systemu światowego według Immanuela Wallersteina, „Przegląd Politologiczny” 2009, nr 1.

Rosenau J.N., Governance in a new global order, [w:] Governing Globalization: Powers, Authority and Global Governance, red. D. Held, A. McGrew, Polity Press, Cambridge 2002.

Strange S., The Retreat of the State. The Diffusion of Power in the World Economy, Cambridge University Press, Cambridge 1996.

Wallerstein I., Koniec świata jaki znamy, Scholar, Warszawa 2004.

Wallerstein I., The Capitalist - World Economy. Essays by Immanuel Wallerstein, Cambridge University Press, Cambridge 1979.

Wallerstein I., The Modern-World System III: The Second Era of Great Expansion of the Capitalist World-Economy 1730-1840, CA: Academic Press, San Diego 1988.

Żyżyński J., Neoliberalizm - ślepa uliczka globalizacji, [w:] Globalizacja, kryzys i co dalej, red. G. Kołodko, Poltext, Warszawa 2010.

Zürn M., The change of globalization and individualization: A view from Europe, [w:] Whose World Order? Uneven Globalization and the End of Cold War, red. H.H. Holm, G. Sørensen, Westview, Boulder 1995.

\section{Źródła internetowe}

CIA World Factbook z 1 stycznia 2012, http://www.indexmundi.com/g/r.aspx?c=ci\&v=69, http://usatoday30.usatoday.com/money/companies/regulation/story/2012-02-27/gordon-gekko-michaeldoiuglas-fbi-psas/53275070/1. 


\section{Transnational historical materialism as a perspective on global governance}

Keywords: transnational historical materialism, global governance, capitalist economy, commodification, globalization, liberalization

Summary

The main purpose of this article is to systematize various positions held by transnational historical materialists in relation to global governance. They believe that the aforementioned phenomenon is a concept whose purpose is to conceal the class character of control practices taking place in the contemporary capitalist economy. The common denominator is the historical relationship between globalization, commodification and liberalization, as processes which became particularly evident in the late 1970s and 80s. Hence, the first part of this article shows criticism of the UN vision of global governance. In the second part, the issue analyzed is embedded in a theoretical outlook, based mainly on the works of Immanuel Wallerstein, Henk Overbeek, Robert Cox, Mark Duffield and Stephen Gill. The article ends with conclusions containing generalizations resulting from the analysis. 